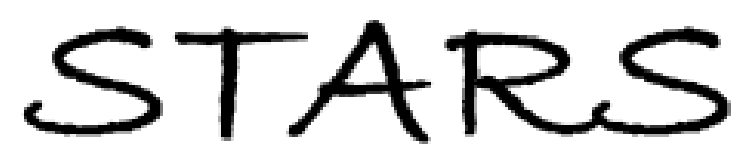

University of Central Florida

STARS

Faculty Bibliography 2010s

Faculty Bibliography

$1-1-2012$

\title{
A General Theory of Climate Denial
}

Peter J. Jacques

University of Central Florida

Find similar works at: https://stars.library.ucf.edu/facultybib2010 University of Central Florida Libraries http://library.ucf.edu

This Article is brought to you for free and open access by the Faculty Bibliography at STARS. It has been accepted for inclusion in Faculty Bibliography 2010 s by an authorized administrator of STARS. For more information, please contactSTARS@ucf.edu.

\section{Recommended Citation}

Jacques, Peter J., "A General Theory of Climate Denial" (2012). Faculty Bibliography 2010s. 2793.

https://stars.library.ucf.edu/facultybib2010/2793

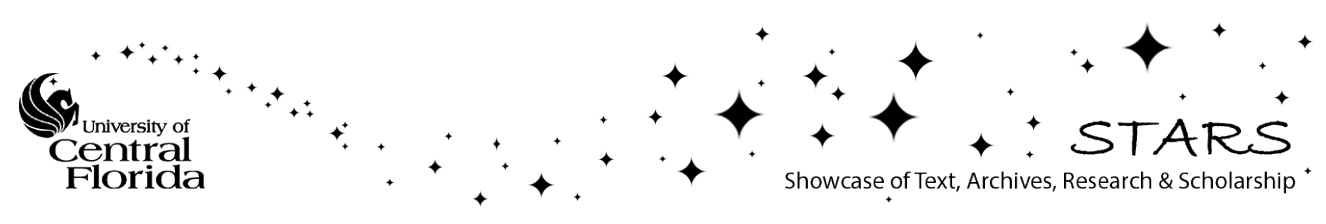




\title{
A General Theory of Climate Denial
}

\author{
Peter J. Jacques
}

There is now a well-recognized right-wing counter-movement challenging the trend, attribution, impact, and civic implications of orthodox climate change science. Where do the body and spirit of this counter-movement come from? Here I will reflect on some conspicuous questions. First, why have academics, the media, and the counter-movement itself had difficulty naming the countermovement? Second, why reject the premise of global environmental change at all? Finally, what is the result of the apparent binary choice between the acknowledgment of the orthodoxy and its rejection?

\section{A General Theory of Denial}

I will argue that climate denial is an appropriate label consistent with Lang's "General Theory of Historical Denial." ${ }^{1}$ Currently, there is disagreement whether climate "skeptic," "contrarian," and "denier" are representative terms. ${ }^{2}$ I have used the word "skeptic," but I admit here and elsewhere that it is inappropriate, ${ }^{3}$ because the skepticism in environmental skepticism is asymmetrical. As skeptics cast doubt on ecological science, they have an abiding faith in industrial science and technology, free enterprise, and those great institutions of Western Enlightenment. ${ }^{4}$ Further, skeptics rightfully argue that skepticism is a fundamental sentiment of rigorous science. Ecological cynicism is then positioned as scientific without drawing attention to the asymmetry.

Lahsen has successfully used the word "contrarian" to denote the most outspoken leaders of climate rejection, particularly credentialed physicists and climate scientists such as Frederick Seitz, Robert Jastrow, William Nierenberg, Willie Soon, and Sallie Balliunas. For political and ideological reasons, these "contrarians" provide "authority" to challenge climate science basics. ${ }^{5}$ This word, too, has problems, however. "Contrarian" works well for the aforementioned scientists, but the climate skeptic position has become, at least in the US, a more populist position. ${ }^{6}$ The skeptical counter-movement led by conservative

1. Lang 2010, 162.

2. Anderegg et al 2010a; Anderegg, Prall, and Harold 2010b, O'Neill and Boykoff 2010.

3. Jacques 2009.

4. Kysar 2003.

5. Lahsen 1999 and 2008.

6. See for example, Dunlap and McCright 2008. 
think tanks has spread the seeds of climate discontent effectively, and these seeds have sprouted in a nation now relatively sympathetic to bumper stickers that say "stop global whining." Finally, "contrarian" has a flavor of heroic daring, a David versus Goliath connotation of debunking myths from a repressive mainstream through courage and intelligence the rest of us lack. Indeed, some of the aforementioned leaders see themselves in the context of scientific history in which heroic contrarians face Copernican opposition but expect to be vindicated. $^{7}$

Finally, there is the word "denial." For O'Neill and Boykoff, the connections to Holocaust denial make "denier" inappropriate and insensitive, and I sympathize with this logic. ${ }^{8}$ However, if we look to the scholarship of Holocaust denial itself, we discover that denial is more than a "blind moral insult."

Holocaust denial researcher Lang notes that denial is a genre that "does not imply equivalence among its instances, but it does suggest a common trope figuring the space between atrocity and its historical narratives." Denial is not an "occasional deviant narrative" but a common "historiographic category" that presents a "general theory of historical denial." Climate denial is not an atrocity in the strict sense, but the framework fits.

Deborah Lipstadt explains the architecture of reasoning in Holocaust denial: (1) It is a movement. (2) It is a defense of a threatened ideology. (3) Its true objectives are camouflaged. (4) Its tactics include sowing confusion through the creation by creating knowledge claims that appear legitimate to the general public.

These criteria mark out a general theory of denial compatible with Lang's suggestions. The purpose of Holocaust denial has been to promote an international movement for right-wing National Socialism. The "Holocaust myth," according to some deniers, threatened the "survival of the Race itself." ${ }^{10}$ In other words, the Holocaust threatened fascists in ontological terms. The Holocaust denial movement deploys truths mixed with lies, through personalities with "slight professional credentials"11 who state that their real goals are to "uncover historical falsehoods" and debunk the "Holocaust hoax" and propaganda. The movement sows confusion and demands space for two competing and supposedly equally valid sides in a public debate that adherents say deserves equal treatment. ${ }^{12}$

Climate change and the Holocaust are not equivalent, but that does not mean there is no climate denial. For example, Richard Lindzen has publicly taken on this label because he believes dangerous climate change has so little validity that there is nothing to be skeptical about. ${ }^{13}$

7. Eg, Spencer 2008.

8. O'Neill and Boykoff 2010.

9. Lang 2010.

10. Richard Verrall, aka Richard Harwood, quoted in Lipstadt 1993, 106.

11. Lang 158.

12. Lipstadt 1993, 4.

13. Carr, Howie. Richard Lindzen: Global Warming Denier. Boston, MA: WRKO AM 680, 2009. Ac- 
Climate skepticism comes as an anti-reflexive counter-movement to beat back the ontological threats to Western modernity, organized through conservative think tanks, mostly in the US, with some in the UK. ${ }^{14}$ The true ideological and material objectives of the counter-movement are camouflaged by several tactics that confuse fair-minded citizens but empower those ready to deny climate change. ${ }^{15}$ While most climate deniers do not have substantial climate expertise, ${ }^{16}$ well-credentialed contrarians serve as spokesmen (mostly men) to media forums outside peer-reviewed journals. Thus, it appears to policy elites, journalists, and of course the general public that there are two equally legitimate "sides" and that each should receive equal attention. ${ }^{17}$ Climate denial advocates sow confusion in a public that is often unaware that core elements of climate science have far more vetting, good-faith witnesses, corroboration, and merit.

Holocaust denial prompts several relevant questions: (1) What difference would it make if the counterfactual assertion proposed were acknowledgedspoken-by the school of Holocaust denial? ${ }^{18}$ Why Holocaust denial at all? And why anti-semitism? (2) Are there any benefits to Holocaust denial? (3) Is the apparent binary choice between "denial" and "acknowledgment" adequate?

Regarding climate change, what difference would it make if climate deniers admitted dangerous climate change was afoot? It would, in fact, suggest that there is a bridge for agreement between denial and other positions, because-while not explicitly stated by deniers, climate denial itself implies that if climate change were a real threat, the international community must act decisively. Why climate denial at all? I submit that climate change science provides an imminent critique of industrial power, Western modernity, and the ideals of Western progress, just as the study of ecology was at first seen as a "subversive" force because, if it were taken seriously, it would challenge the central workings of "modern" society. ${ }^{19}$

Have there been benefits to the counter-movement? Yes. It has pushed climate change scientists to articulate themselves more clearly, and it has provided an incentive for social and ecological sciences to look deeply into climate dynamics. In some sense, climate denial has given climate researchers more urgency. That said, the challenge from climate deniers has also created acute democratic and civic problems. One problem is a science trap, where elites and masses cannot differentiate between authentic controversy in scientific literature, and manufactured controversy outside of the literature, in part because one has to be an expert in that literature to know the difference. Some experts in the

cessed http://audio.wrko.com/m/audio/24111309/richard-lindzen-global-warming-denier.htm, May 25, 2010.

14. Jacques et al 2008; McCright and Dunlap 2003, 2008, 2010.

15. Hoggan and Littlemore 2009; Oreskes 2010; Powell 2011; Washington and Cook 2011.

16. Anderegg et al 2010.

17. Boykoff and Boykoff 2004; Boykoff 2007; Boykoff 2009; Lahsen2005; Antilla 2005.

18. Lang 2010, 159.

19. Sears 1964. 
literature, like climatologists, can deploy their own expertise in a way inconsistent with that literature for ideological reasons, yet most people will not know the difference. In this way the expert climate deniers are a "real, organic vanguard of the upper classes" of the global North. ${ }^{20}$

In addition, the email hacking of climate science computers at the University of East Anglia demonstrated that beleaguered scientists felt they needed a united front. The confrontation between denial and the mainstream paradigm has Balkanized into false binary positions where any diversity within the mainstream is seen as support for denial. However, a warning from Gramsci is relevant:

Herein is revealed the truth of a criterion of historico-political research: there does not exist an independent class of intellectuals, but every class has its intellectuals; however, the intellectuals of the historically progressive class [those who 'push society forward'] exercise such a power of attraction that, in the final analysis, they end up by subordinating the intellectuals of the other classes and creating an environment of solidarity among all the intellectuals, with ties of a psychological (vanity, etc.) and often of a caste (technico-juridical, corporate) character. ${ }^{21}$

I take this to mean that it is dangerous to look upon the orthodox position as overly homogenous. Gramsci considered this type of mistake an "Enlightenment error." This allows for a concentration of power, and an obfuscation of varied interests hidden in the homogeneity. Such diversity is not about challenging well-adopted aspects of climate physics, but more about "the adaptation of each basic concept to diverse peculiarities, presenting and re-presenting it in all its positive aspects and in its traditional negations, always ordering each partial aspect in the totality." 22 I think, for example, of some in the orthodox position calling for geoengineering as a "substitute for social change," a position that carries considerable ecological, scientific, and ethical problems. ${ }^{23}$ Certainly climate academics come to the meaning of climate change through more than material interests, but our positions themselves are not classless or without material implications, and these implications matter for the rest of the world. Further, the mainstream agreement about the basics of climate change is certainly political in the sense that Goeminne notes in this forum, and we would be amiss to think that the consensus did not have its own political motives, which notably include some subversive elements noted above. But, even if all science must deal with ideology, not all subjectivities are equally defensible. The subjectivity and choices made within mainstream climate science have intersubjective agreement, where judgments must be accountable to scrutiny, witness, and vetting, not to mention corroboration and revision. Climate denial is mostly expressed in forums where the scrutiny is internal and guided by ideology, say

20. Gramsci, 1992, 137.

21. Ibid, 137-8.

22. Ibid, 128 .

23. Hamilton 2011, 2. 
within the conservative publisher or the think tank, unlike the external evaluation that relies on peer review. Such a process is certainly political, but if all knowledge production is political, accountability to a process that holds authors accountable for critique, review, and forces revision provides higher degree of confidence and validity that deserves conditional trust, around which a community vision of reality can form.

\section{Science and Deviants}

Does identifying a range of positions for climate acknowledgment mean climate denial is more legitimate? Lang marks out several positions regarding Holocaust acknowledgment, but none of these positions make Holocaust denial any more legitimate. Having a diversity of positions in relation to acknowledgment of the orthodoxy and denial does not mean each position has equal merit intellectually, civically, or morally.

Take for example the Ukuku people of Peru, who have been watching their sacred glaciers melt in the Andes. Wall Street Journal correspondent Anthony Regalado reported in 2005, "Amid Peru's high mountains, where locals scratch a living from potatoes and alpaca wool, most people have little idea that changes to their climate may be caused by global warming." 24 The Ukuku therefore do not acknowledge the orthodox climate science position, but the orthodox position does not live on the mountain with them. This does not mean, however, that the Ukuku are being irresponsible citizens, or that they are sowing confusion to promote their own privilege. They have now prohibited themselves from taking ice from the glacier because they want to protect it, because that is where the mountain gods live. And, "The cosmological implications of the missing snow are clear to people here. According to local myth, when the snow disappears from the tops of the mountains, it will herald the end of the world." ${ }^{\prime 25}$ The willful attacks on science by the counter-movement mislead the public and work to stall accountability, civic obligation, and critical ecological problemsolving in ways that make the counter-movement different not only epistemologically, but morally.

Another civic problem that comes with the presentation of a binary position of acknowledgment versus denial is an oversimplified presentation of complex issues to a population that sees scientific theories as something you "believe in" or "don't," instead of contingent and qualified theories negotiated by method, artifacts, and time. Evolutionary pressures upon the human family will be unchanged by our beliefs; however, our ability to create "more accurate models, metaphors, and measures to describe the human enterprise relative to the biosphere," will likely change our capacity and willingness to work towards sustainability.

What does it mean that some of the leaders of orthodox climate science

24. Wall Street Journal, June 17, 2005, A1.

25. Ibid. 
have felt the need for a united scientific front? At least in part, it implies a presumed need for science to be consumed in a binary form for public action. The structure of the binary form means that complexities and advances can become crises of appearance. Thus one political-scientific question is, What elements of the consensus view shift, and why?

As I write this, debate about cosmic rays (and therefore solar radiation) has emerged from a 2011 publication in Nature showing that cosmic rays may potentially, and substantially, affect cloud formation and have climatic implications. ${ }^{26}$ Rahmstorf admits that these dynamics (in some combination) affected past climates, but that "while reconstructions of solar activity do indicate a rise until 1940, they show no significant trend since then. The same is true of measurements of cosmic rays." 27

Still, orthodox climate science has consistently noted that the role of aerosols is one of "dominant uncertainties" of mainstream climate science. ${ }^{28}$ Currently, "The IPCC estimates that the negative radiative forcing resulting directly from all anthropogenic aerosols ... offsets about one-third of the positive forcing from greenhouse gases, with indirect effects . . . offsetting, in aggregate, roughly another third." ${ }^{29}$ Thus, the current mainstream deals with both the cooling effect of aerosols and the uncertainty that is lessening but is still relatively deep. The current dominant scientific paradigm accounts for this uncertainty, but revolutions are always possible, which should inspire humility in our discourses. But, to the degree that climate science discourses are presented as dichotomies, any qualification to the orthodoxy appears to strengthen denial. Indeed, some news groups demonstrate this by seizing on the uncertainty about aerosols and cosmic rays as invalidating basic climate science, eg, the 2011 European Union Times headline: "CERN: The Sun Causes Global Warming."

When the mainstream reinforces a binary field, it also defends some of the core Enlightenment politics of science-as-authority and antidote-to-ideology, which may add legitimacy to projects like geoengineering or nuclear energy. When the public is presented with false dichotomies like "acknowledgment" or "denial," policy choices may become Hobson's choices.

Further, a binary presentation of key knowledge claims erects the political scaffolding for partisans. For climate change discussions in the US, we have witnessed the social fabrication of divergent realities. Conservative and liberals choose media that represent different predetermined realities, pruning down the "common" sense needed for community deliberations about authentic solutions. ${ }^{31}$

26. Kirkby et al 2011.

27. Rahmstorf 2005, 79.

28. Mastrandea and Schneider 2010; Rahmstorf 2005; Solomon et al 2007.

29. Mastrandea and Schneider, 19.

30. European Union Times, "CERN: The Sun Causes Global Warming" September 3rd, 2011, online at http://www.eutimes.net/2011/09/cern-the-sun-causes-global-warming/.

31. McCright 2011. 
Just as the binary position oversimplifies orthodoxy, it also obscures other important aspects that lie outside willful denial, as well as outside the orthodox position. As Lang put it with Holocaust denial: Are there other options? Yes, and they do not necessarily support denial of the Holocaust because there are, for example, those who do not or cannot know about the Holocaust.

Likewise, the insightful work of Kari Norgaard has shown that climate change challenges the ontological security of some peoples so much that they use denial as a matter of psychological protection. ${ }^{32}$ This type of denial is without a political movement, and is a perfectly understandable, if ineffective, response that really helps us understand something about science and social change.

\section{In Sum}

The counter-factual for climate deniers is that climate change is an authentic threat. The implied reason for their movement is that, if they were to consider the counter-factual real, they would agree it needs effective and decisive action on multiple intersecting scales. At the same time that climate science offers imminent critique of the industrial base of Western modernity, it tempts us to think of authentic changes to the world political economic structure because it is so irreparably unsustainable. At the same time, strains are evident within the orthodoxy that also appear to defer serious alternatives to social change, and this is a (albeit unintentional) reverse bridge to the social motives of the counter-movement to the extent that both present the sentiment that the industrial way of life is non-negotiable. ${ }^{33}$

In the end, lessons from Holocaust denial research show us the field is not dichotomous even in that case, but there are fundamental aspects to the history of denial. One theoretical key is that organized deflection of accountability is driven by a movement aimed at defending an ideology, and it does so through surreptitious means. "Acknowledgment" and "denial" are not the only choices, but this diversity does not make organized and willful denial more ethically or epistemologically defensible. The climate denial counter-movement comes from, I posit, the defensive fear that the possessive individualistic ontology of the West lies uncomfortably in the guillotine.

\section{References}

Anderegg, William R. L., James W. Prall, and Jacob Harold. 2010a. Reply to O'Neill and Boykoff: Objective Classification of Climate Experts. Proceedings of the National Academy of Sciences 107 (39), E152.

Anderegg, William R. L., James W. Prall, Jacob Harold, and Stephen H. Schneider. 2010b.

32. Norgaard 2006 and 2011.

33. To paraphrase George H. W. Bush at the Rio "Earth" Summit in 1992. 
Expert Credibility in Climate Change. Proceedings of the National Academy of Sciences 107 (27), 12107-12109.

Antilla, Liisa. 2005. Climate of Scepticism: U.S. Newspaper Coverage of the Science of Climate Change. Global Environmental Change 15 (4), 338-352.

Arendt, Hannah. 1963. Eichman in Jerusalam: A Report on the Banality of Evil. New York: Penguin.

Boykoff, Maxwell, and Jules Boykoff. 2004. Balance as Bias: Global Warming and the US Prestige Press. Global Environmental Change 14 (2), 125-136.

Boykoff, Maxwell T. 2007. From Convergence to Contention: United States Mass Media Representations of Anthropogenic Climate Change Science. Transactions-Institute of British Geographers 32, 477-489.

. 2008. Lost in Translation? United States Television News Coverage of Anthropogenic Climate Change, 1995-2004. Climatic Change 86 (2), 1-11.

Dunlap, R. E., and Aaron M. McCright. 2008. A Widening Gap: Republican and Democratic Views on Climate Change. Environment 50 (5), 26-35.

Gramsci, Antonio. 1992. Prison Notebooks. New York: Columbia University Press.

Jacques, Peter J. 2009. Environmental Skepticism: Ecology, Power, and Public Life. Burlington, VT, and Surrey, UK: Ashgate Publishing Ltd.

Jacques, Peter J., Riley E. Dunlap, and Mark Freeman. 2008. The Organization of Denial: Conservative Think Tanks and Environmental Scepticism. Environmental Politics 17 (3), 349-385.

Kirkby, Jasper, Joachim Curtius, Joao Almeida, et al. 2011. Role of Sulphuric Acid, Ammonia and Galactic Cosmic Rays in Atmospheric Aerosol Nucleation. Nature, 476 (7361), 429-433.

Kysar, Doug. 2003. Some Realism About Environmental Skepticism: The Implications of Bjørn Lomborg's the Skeptical Environmentalist for Environmental Policy and Law. Ecology Law Quarterly 30 (2), 223-278.

Lahsen, Myanna. 1999. The Detection and Attribution of Conspiracies: The Controversies over Chapter 8. In Paranoia within Reason: A Casebook on Conspiracy as Explanation, edited by G. E. Marcus, 111-136. Chicago: University of Chicago Press. 2005. Technocracy, Democracy, and U.S. Climate Politics: The Need for Demarcations. Science, Technology, and Human Values 30 (1), 137-169.

2008. Experiences of Modernity in the Greenhouse: A Cultural Analysis of a Physicist "Trio" Supporting the Backlash against Global Warming. Global Environmental Change 18 (1), 204-219.

Lang, Berel. 2010. Six Questions on (or About) Holocaust Denial. History \& Theory 49 (2), 157-168.

Lipstadt, Deborah E. 1993. Denying the Holocaust: The Growing Assault on Truth and Memory. New York: Free Press.

Mastrandea, Michael D., and Stephen H. Schneider. 2010. Climate Change Science Overview. In Climate Change Science and Policy, edited by S. Schneider, A. Rosencranz, M. Mastrandea, and K. Kuntz-Duriseti, 11-27. Washington DC: Island Press.

McCright, Aaron, and Riley E. Dunlap. 2003. Defeating Kyoto: The Conservative Movement's Impact on U.S. Climate Change Policy. Social Problems 50 (3), 348-373.

McCright, Aaron M. 2011. Political Orientation Moderates Americans' Beliefs and Concern About Climate Change. Climatic Change 104 (2), 243-253.

McCright, Aaron M., and Riley E. Dunlap. 2010. Anti-Reflexivity: The American Conser- 
vative Movement's Success in Undermining Climate Science and Policy. Theory Culture Society 27 (2/3), 100-133.

Norgaard, Kari. 2011. Double Realities: Global Warming and the Social Organization of Climate Denial. Cambridge, MA: MIT Press.

Norgaard, Kari Marie. 2006. "We Don't Really Want to Know": Environmental Justice and Socially Organized Denial of Global Warming in Norway. Organization \& Environment 19 (3), 347-370.

O’Neill, S. J., and M. Boykoff. 2010. Climate Denier, Skeptic, or Contrarian? Proceedings of the National Academy of Sciences of the United States of America 107 (39), E151.

Powell, James Lawrence. 2011. The Inquisition of Climate Science. New York: Columbia University Press.

Riley E. Dunlap, and Aaron M. McCright. 2008. Social Movement Identity: Validating a Measure of Identification with the Environmental Movement. Social Science Quarterly 89 (5), 1045-1065.

Sears, Paul B. 1964. Ecology: A Subversive Subject. Bioscience 14 (7), 11-13.

Solomon, S., D.Qin, M.Manning, et al, eds. 2007. Climate Change 2007-The Physical Science Basis: Contribution of Working Group I to the Fourth Assessment Report of the IPCC. Cambridge, UK, and New York, NY: Cambridge University Press.

Spencer, Roy. 2008. Climate Confusion: How Global Warming Leads to Bad Science, Pandering Politicians and Misguided Policies That Hurt the Poor. New York: Encounter Books. 